\title{
THE CONCEPT OF SOCIO-PEDAGOGICAL COMPETENCE OF FUTURE SOCIAL TEACHERS IN THE SYSTEM OF PROFESSIONAL TRAINING FOR WORK WITH RURAL YOUTH
}

\author{
Oksana Opanasenko \\ Postgraduate Student, National University of Life \\ and Environmental Sciences of Ukraine, Ukraine \\ e-mail: OpanaO@i.ua, orcid.org/0000-0003-1487-422X
}

\section{Summary}

The article justifies the concept of socio-pedagogical competence of a future social teacher in the context of his training for work with rural youth. The notions "pedagogic concept" and "competence" are defined. The author analyses and specifies the key tasks of the formation of the pedagogic competence of a specialist. European and Ukrainian documents relating to the general requirements for a personality and professional competence of a future specialist are examined. The research also generalizes and systemizes the achievements of scientists in the area of professional training of social teachers, including in the context of the case study of the interrelation of competences and expertise, elaboration of requirements for competence and their assessment.

The article's goal is determined. The author highlights the fundamental principles which are a basis for the development of a professional competence of social teachers. It is outlined the key education competences through the primary targets of general education, a structured presentation of social experience and personal experience as well as core types of activity which allow mastering social experience, acquiring life and practical skills in the modern society.

The research defines the basic concepts which are a framework for the development of a professional competence of future social teachers.

The general professional requirements for a personality and professional competence of a specialist - a social teacher - are marked according to the national education standards. The qualification characteristics of the profession "social teacher" are described.

It is mentioned a statutory ground for the implementation of a competency-based approach and studied an educational and professional program in the specialty 231 Social work, subject area 23 Social work, which contributes to the training of future specialists in the National University of Life and Environmental Sciences of Ukraine.

Keywords: educational process, higher education institution, social experience, self-improvement, competence, knowledge, skills.

\section{DOI https://doi.org/10.23856/3926}

\section{Introduction}

Despite the current challenges, the issue of professional training of socio-pedagogical staff is of the most immediate interest in the context of higher professional education as it plays a key role - the provision of labour market of Ukraine with highly-skilled specialists.

The educational processes are open for the global social shifts, which are driven by scientific and technical progress, a rapid IT development, computerization and democratization of the entire social life of our state. Under the conditions resulting from the sweeping social and economic changes, the process of professional training comes into sharp focus as a factor of 
the social development through the professional development of every individual by virtue of a competency-based approach in terms of the whole educational paradigm.

The achievements of scientists dealing with the professional training of social teachers are generalized and systematized. In essence, the issue of professional training of future social teachers has been reflected in the scientific guidelines of the theory of social pedagogy (I. Zvierieva, M. Halahuzova, A. Kapska, L. Koval, A. Mudryk, A. Ryzhanov); social and pedagogical work with children and young people (O. Bezpalko, H. Laktionova, Yu. Polishchuk, V. Teslenko). The research papers of Ukrainian scientists cover the issue of professional training of a future social teacher (R. Vainola, L. Mishchyk, V. Polishchuk, S. Kharchenko, N. Tverezovska, L. Viktorova et al.); A. Aleksiuk, V. Bezpalko, R. Vainola, V. Haluzynskyi, M. Yevtukh, L. Zavatska, Zvierieva, Ziaziun, A., Kapska, O., Karpenko, L. Mishchyk, N. Nychkalo, T. Semyhina, I. Trubavina have considered general-theoretical training and content of the professional education; A. Boiko, S. Honcharenko, I. Ivanova et al. have dealt with the research of professional skills. A competency-based approach under the framework of training of specialists in the higher education institutions has been studied by V. Bolotov, A. Ovcharuk, O. Pometun, S. Kubitskyi, M. Mykhailichenko O. Savchenko, S. Trubachova et al. J. Raven, A. Khutorskoi, N. Bibik, L. Vashchenko, I. Iermakov, O. Lokshyna, O. Ovcharuk, L. Parashchenko, O. Pometun, O. Savchenko have analyzed the interrelation of competences and expertise, elaboration of the requirements for competence and their assessment (Shevtsiv Z. M., 2017). O. Arnautov, V. Bocharova, Yu. Vasylkova, M. Halahuzova, R. Ovcharova et al. have described the basic requirements for the professional competence of a social teacher.

The purpose of the research is to substantiate the concept of socio-pedagogical competence of future social teachers in the system of professional training for work with rural youth.

\section{The statement of the basic material}

Pedagogical concept is a system of views of a particular pedagogical phenomenon, process, way of thinking, interpretation of some pedagogical phenomena, experience; the basic idea of pedagogical theory (Honcharenko S.U., 1997). Every pedagogical concept aims to bring up an active, creative individual, who can master modern information and communication technologies, take part in the independent search, make own discoveries, render decisions independently and take responsibility for an outcome.

Analysis of modern pedagogical concepts has confirmed they are grounded on the problem-based learning, which involves focusing on a student, taking into account his rights and various needs; forming of skills and abilities of mental activity; developing of multiliteracy and communicative competence for an active realization in a polycultural environment; students' gaining experience in carrying out research activity when investigating urgent social problems; dynamic participation of all subjects of the educational process in the process of negotiation; activation of interrelation between a school and the external environment etc. (Kuzmenko O. M., 2015).

Competence (from Latin "competentia") means the set of issues a person well-informed about, has knowledge and experience (Khutorskoi A.V., 2003). An employee's competence is the level of his qualification, which permits solving the tasks set effectively (Busel V.T., 2002).

The research analyses and specifies the key tasks of the development of pedagogical competence of a specialist: to ensure the mastering of technologies of self-organization and self-actualization; to lay the groundwork for the evolvement of the professional culture of a specialist; to promote the formation of core competences; to organize professional mobility; to raise social activity through the prism of personal qualities and social skills of an individual 
(Bereka V. Ye. et al, 2018). The list of core education competences is established following the primary targets of general education, a structured presentation of social experience and personality experience as well as principal activities, which make it possible to master a social experience, to acquire life and practical skills in the modern society. Taking into account the above points, the core education competences are as follows: axiological competence; culture-universal competence; cognitive competence; information competence; communicative competence; social-labour competence, competence of personal self-development (Khutorskoi A.V., 2003).

Among the studied concepts "expertise" and "competence", the author gives prominence to the definition of competences as a standard of actions, knowledge, skills, creative work, emotional and axiological activity; the definition of competence as the level of the competences' achievement by an individual; and, at the same time, it seems expedient to be limited by one term - "competence" - amidst the principal indicators of qualification of a future specialist (Nikolaiev O.M., 2012).

Professional competence of a future social teacher for work with rural youth in the system of professional training is specified according to the state education standards, which involve general requirements for an individual and professional competence of a specialist. Qualification characteristics of posts provide for a specific list of official duties for a social teacher taking into account his rights, responsibilities and competences.

OECD (Organisation for Economic Cooperation and Development) defined nine core skills determining an individual's competence: the ability to interact in heterogeneous groups; the ability to use modern technology interactively; the ability to use modern information technologies and to communicate; the ability to solve problems; the ability to listen to other person and to take his standpoint into consideration; the ability to use variable information sources; the ability to find a common language; the ability to combine and to be oriented in diverse information content; the ability to console oneself in moments of uncertainty; the ability to organize and assess own activity (Chernii L.V., 2008).

The National Strategy of Education Development in Ukraine for 2012 - 2021 states "education is a strategic resource of socio-economic, cultural and spiritual development of the society, improvement of the public welfare, guarantee of the national interests, strengthening of the international standing and image of our state, creation of conditions for every individual" (Natsionalna stratehiia rozvytku osvity v Ukraini, 2013).

The development of professional competence of social teachers is based on several fundamentals. First, it is a lifelong learning process. Second, it is the development of the skill to observe, analyse the effects and influence of different methods, means; the ability not only to adapt own knowledge to individual needs of beneficiaries but also to correlate own experience with the experience of colleagues. Third, in the context of the study of the issue of development of professional competence, social teachers can be divided into three groups: social teachers who are loath and can't critically evaluate their practice and thus, don't assume the role of others in this task; specialists who can and wish analyzing their practice and introducing modifications relying on the findings (Pidhotovka pedahohiv do zastosuvannia innovatsiinykh metodiv navchannia, 2007).

According to the Order of the MES dated 01.06.13 № 665 "On Approval of Qualification Characteristics of Professions (Posts) of Teaching and Academic Staff of the Education Institutions", a social teacher shall know the following: the Constitution of Ukraine, the Law of Ukraine "On Education", social security legislation of Ukraine; statutes and regulations on training and education of children with disabilities; labour legislation. A social teacher has specific tasks and obligations, namely: to study, generalize and implement new teaching and educational methods; to keep records relating to children who need a social rehabilitation: their 
personal files, correspondence with executive authorities, subjects of preventive-educational and therapeutic rehabilitation, parents (and authorized persons as well); to draw up programs of educational and rehabilitation work; to be a mediator between education institutions, family, staffs, the public and to organize their cooperation; to pool efforts for laying a groundwork for a holistic development of children and teenagers within the social environment; to maintain social work on the establishment of communication between children, young people and grown-ups of the community according to place of residence; to contribute to the participation of children and young people in scientific, technical, sports, artistic endeavours, socially beneficial activities; to assist in overcoming inter-personal, family conflicts, to provide necessary consulting psychological-pedagogical aid for children's and youth non-governmental organizations, social risk groups, children and minors who require help; to disseminate the guidelines meeting the principles of universal human morality, justice, humanism, kindness, hard work and other virtues; to promote respect to parents, a woman, cultural-national, spiritual, historical values of Ukraine, taking good care of the environment; to prepare children and minors for a social life following the principles of sympathetic understanding, peace, consent, respect; to abide pedagogical ethics, to upgrade the professional level, teaching skills; to improve professional and qualification level. (Nakaz MON № 665, 2013).

The model of professional competence of a social teacher involving professional knowledge, professional skills and abilities, professional personal qualities, professional image and job description, which fixes the general requirements for a specialist's qualification at the level of his theoretical and practical experience, fully conveys the desired result upon the completion of professional training of future social teachers for work with rural youth in a higher education institution.

Sorbonne Joint Declaration and Bologna Declaration conceptualized theoretical frameworks of the implementation of a competency-based approach as a key pillar of the new education paradigm and indicator of the creation of a unified European space. In Ukraine, the National Doctrine on the Development of Education, the Order of the Ministry of Education and Science, Youth and Sports of Ukraine "On the Approval of Action Plan on Quality Assurance of Higher Education in Ukraine and Integration into European and World Educational Community" as well as other programs and arrangements form a regulatory framework for the implementation of a competency-based approach. A competency-based approach is conditioned by - the switch of the world community to an information-oriented society where the priority is not only the accumulation of knowledge, skills and abilities of future specialists but the mastery of skills of data retrieval, the ability to self-education during the training and professional activity; the need to be competitive which requires of the system of higher education the provision of future specialists with the common opportunities for the integration into different communities, dynamic actions, self-improvement (Veretenko T. H., 2012).

The National University of Life and Environmental Sciences of Ukraine trains specialists for socio-pedagogical activity. The focus of the training is to get knowledge of social and pedagogical work, other human and social sciences to the full extent; the personal, professional, social development of students. The training is based on the general scientific foundations, ongoing experience of the practical social and pedagogical work, teaching in a HEI and focused on the relevant specializations which make a professional activity within their scope possible. The primary approaches, methods and technologies which are used while learning are as follows: the person-oriented, competency-based, systems approaches, student-centered learning, problem-based learning, hands-on learning, self-education. The study style is active (Tverezovska N.Tet al., 2019).

The National University of Life and Environmental Sciences of Ukraine trains future specialists according to all qualification requirements. 
Within the framework of the research, the author has studied the current status of the development of professional competence of future social teachers among Master students of the National University of Life and Environmental Sciences of Ukraine via interrogating and questionnaire survey. There are the following findings: the value-motivational criterion shows that the structure of professional motivation of social teachers, which is characterized by an internal motivation to form professional competence, confirms a conscious choice of the profession. According to the cognitive-information criterion, the development level of professional competences is sufficient for social teachers, who have the relevant professional education and practical experience gained during the work experience internship during the period of university study.

The predictive and reflective criterion of the level of professional competence of social teachers confirms the focus on the enhancement of professional competence.

The outcome of social and communicative criterion demonstrates the ability of future social teachers in the system of professional training for work with rural youth to establish a sincere, emotional, unbiased communication with colleagues and clients in order to provide social and pedagogical assistance.

The research has justified a high level of the integral criterion of professional competence of future social teachers of the National University of Life and Environmental Sciences of Ukraine.

The educational and scientific program in specialty 231 Social work, subject area 23 Social work, specifies the following professional competences: integral competence - the ability to solve challenging professional and practical tasks in the area of social work or during the process of training, which involves using particular theories and methods of social work and has a complex nature and ambiguity of conditions. General competences are as follows: the ability to think abstractly, analyze and synthesize; the ability to apply knowledge in practical situations; the ability to plan and manage time; knowledge and understanding of the subject area and professional activity as well; the ability to communicate in the state language both verbally and in writing; IT skills; the ability to learn and master modern knowledge; the ability to search, process and analyze various information; the ability to identify, put and solve problems; the ability to make grounded decisions; the teamwork ability; communication skills; the ability to motivate people and move towards a common goal; determinacy and persistence on the tasks and duties taken; the ability to act socially and consciously. The specialty includes the following professional competences: the ability to evaluate socio-psychological phenomena associated with the state's social development; the ability to analyze the legal and regulatory framework for social work and social security; the ability to analyze psychological attributes, status and processes of formation, development and socialization of the individual, the development of social group and community; the ability to avert possible social risks, difficult living conditions, prevent and solve social conflicts; the ability to understand the organization and functioning of the system of social protection and social services; the ability to consider a social problem using methods and forms of social and pedagogical work in the context of a particular situation; the ability to assess problems, needs, features and resources of clients; the ability to develop ways to overcome social problems and find effective ways for their solution; the ability to provide assistance and support to clients, taking into account their individual needs, age differences, gender, ethnic and other characteristics; the ability to initiate social changes aimed at raising social well-being; the ability to elaborate and implement social projects and programs; the ability to apply management methods to organize own professional activities and control the actions of social workers, volunteers and other staff; the ability to interact with clients, representatives of various professional groups and communities; the ability to adhere to ethical principles and standards of social work; the ability to identify and attract the resources of an 
individual, social group and community to fulfill the tasks of professional activity; the ability to generate new ideas and creativity in the professional area; the ability to evaluate the results and quality of professional work in the field of social work; the ability to promote the welfare and social protection of individuals, social assistance and support to those in difficult straits (Tverezovska N.T. et al., 2019).

\section{Conclusions}

The concept of socio-pedagogical competence of future social teachers in the system of professional training for work with rural youth is based on the self-perception of a future specialist as an individual and a high-qualified professional. The issue of competence in the context of students' training has recently become relevant due to the introduction of the educational competency-based approach in theory and practice. Moreover, the competence of a future specialist along with the guidelines of academic disciplines turn into the constituent components of the state educational programs.

A high level of expertise of students - future specialists - is a pillar of their successful adaptation to the living conditions of a dynamic society and ensures the perspectivity for the realization of socio-professional potential.

The directions for future research will include a detailed substantiation of the components of the professional expertise of future social teachers in the system of professional training for work with rural youth and development of technology for its formation.

\section{References}

Bereka V. Ye., Halas A. V. (2018) Profesiina kompetentnist vchytelia pochatkovykh klasiv: navchalno-metodychnyi posibnyk dlia vchyteliv [Professional competence of primary school teachers: a textbook for teachers]. Kharkiv: Ranok. [in Ukrainian]

Busel V. T. (2002) Velykyi tlumachnyi slovnyk suchasnoi ukrainskoi movy [Large explanatory dictionary of the modern Ukrainian language]. Kyiv - Irpin: Perun. [in Ukrainian]

Veretenko T. H. (2012) Formuvannia kompetentnostei maibutnikh sotsialnykh pedahohiv $v$ protsesi profesiinoi pidhotovky [Formation of competencies of future social teachers in the process of professional training]. Visnik Kyivs'kogo universitetu im. B. Grinchenka, no. 10. [in Ukrainian]

Honcharenko S. U. (1997) Ukrainskyi pedahohichnyi slovnyk [Ukrainian pedagogical dictionary]. Kyiv: Lybid. [in Ukrainian]

Kuzmenko O. M. (2015) Suchasni pedahohichni kontseptsii navchannia uchniv starshoi shkoly [Modern pedagogical concepts of teaching high school students]. Osvitolohichnyi dyskurs. [in Ukrainian]

Natsionalna stratehiia rozvytku osvity v Ukraini na period 2012 - 2021 rr.: zatv. Ukazom Prezydenta Ukrainy vid 25.06.2013. №344/2013 (2014). [National Strategy of Education Development in Ukraine for 2012 - 2021: approved by the Decree of the President of Ukraine as of June 25, 2013, №344 / 2013]. [in Ukrainian]

Nikolaiev O. M.(2012) Kompetentnist ta kompetentsiia u suchasnii pedahohitsi yakpedahohichni katehorii [Competency and competence in teaching teachers as a teacher category]. Problemy Suchasnoi Psykholohii, vol.15, pp.410-419. [in Ukrainian].

Nakaz MON № 665 (2013) Pro zatverdzhennia kvalifikatsiinykh kharakterystyk profesii (posad) pedahohichnykh ta naukovo-pedahohichnykh pratsivnykiv navchalnykh zakladiv [On Approval 
of Qualification Characteristics of Professions (Posts) of Teaching and Academic Staff of the Education Institutions]. Kyiv [in Ukrainian]

Pidhotovka pedahohiv do zastosuvannia innovatsiinykh metodiv navchannia / Proekt Svitovoho banku «Rivnyi dostup do yakisnoi osvity»: navchalno-metodychni materialy(2007) [Preparation of teachers for the application of innovative methods training / World Bank Project "Equal Access to Quality Education”: educational and methodical materials][in Ukrainian]

Tverezovska N. T., Viktorova L. V., Kubitskyi S. O., Sopivnyk I. V. (2019) Osvitno-profesiina prohrama «Sotsialna robota» Pershoho (bakalavrskoho) rivnia vyshchoi osvity za spetsialnistiu 231 Cotsialna robota haluzi znan 23 Sotsialna robota. Kvalifikatsiia: bakalavr z sotsialnoi roboty [Educational and professional program "Social work" of the First (bachelor's) level of higher education in the specialty 231 Social work in the subject area 23 Social work. Qualification: Bachelor of Social Work] Kyiv: NUBIP Ukrainy. [in Ukrainian]

Khutorskoi A. V. (2003) Dydaktycheskaia evrystyka. Teoryia y tekhnolohyia kreatyvnoho obuchenyia [Didactic heuristics. Theory and technology of creative learning]. Moskva: MHU. [in Russian]

Chernii L. V. (2008) Klasyfikatsiia profesiinykh kompetentsii vchytelia pochatkivtsia zarubizhnymy naukovtsiamy [Classification of professional competencies of novice teachers by foreign scholars]. Visnyk Cherkaskoho universytetu. Ser.: Pedahohichni nauky, vol. 137, pp. 90 - 94. [in Ukrainian]

Shevtsiv Z. M. (2017). Kontseptsiia formuvannia sotsialno-pedahohichnoi kompetentnosti maibutnoho vchytelia pochatkovykh klasiv inkliuzyvnoi zahalnoosvitnoi shkoly [Concept of formation of social-pedagogical competence of future primary school teacher in inclusive comprehensive school]. Elektron. nauk. fakh. vyd., no.1 (19). [in Ukrainian] 